Article

\title{
The Management of Agricultural Waste Biomass in the Framework of Circular Economy and Bioeconomy: An Opportunity for Greenhouse Agriculture in Southeast Spain
}

\author{
Mónica Duque-Acevedo ${ }^{1}$, Luis J. Belmonte-Ureña ${ }^{2, * \mathbb{D}}$, José A. Plaza-Úbeda ${ }^{2}$ \\ and Francisco Camacho-Ferre ${ }^{1}$ (D) \\ 1 Department of Agronomy, Research Centre CIAIMBITAL. Univesity of Almería, 04120 Almería, Spain; \\ mda242@ual.es (M.D.-A.); fcamacho@ual.es (F.C.-F.) \\ 2 Department of Economy and Business, Research Centre CIAIMBITAL. University of Almería, \\ 04120 Almería, Spain; japlaza@ual.es \\ * Correspondence: lbelmont@ual.es; Tel.: +34-950-214-788
}

Received: 24 February 2020; Accepted: 30 March 2020; Published: 1 April 2020

check for updates

\begin{abstract}
For decades, non-renewable resources have been the basis of worldwide economic development. The extraction rate of natural resources has increased by $113 \%$ since 1990, which has led to overexploitation and generation of vast amounts of waste. For this reason, it is essential that a sustainable development model is adopted-one which makes it possible to produce more food and energy with fewer fossil fuels, low pollutant gas emissions and minimal solid waste. Certain management policies and approaches, such as the strategy of a circular ecocomy or bioeconomy, are oriented towards sustainable production and consumption. The present study focuses on the importance of intensive horticulture in the Mediterranean region, specifically in the province of Almería (Spain). After having conducted a study of the main crops in this area, it was determined that the waste biomass generated presented strong potential for exploitation. With the proper regulatory framework, which promotes and prioritises the circularity of agricultural waste, there are several opportunities for improving the current waste management model. In the same way, the results of the economic evaluation demonstrate that the alternative of self-management of waste biomass is profitable, specifically from tomato crops. Compost and green fertilizer production also prove to be a key strategy in the transition towards a more circular and sustainable agricultural production model. As for the said transition, government support is vital in terms of carrying out awareness campaigns and training activities and providing financing for Research and Development (R\&D).
\end{abstract}

Keywords: sustainable development; biomass; family business; greenhouse crops; circular economy; bioeconomy

\section{Introduction}

\subsection{Intensive Farming under the New Model of Sustainable Development}

Dating back more than 10,000 years, agriculture has provided society with basic products-such as foods, fibers and fuels, among others-which have been necessary for the development of processes essential for life on Earth and human evolution [1,2]. Natural resources, especially land and water, have been the main sustenance for agricultural production [3], which has grown more than three-fold in the last 50 years [4]. This growth has made agriculture the largest and most important economic sector in many countries and the sector that generates the most jobs in the world [5]. This "green 
revolution" transformed the world of agriculture [1] by increasing the use of agricultural inputs and allowing maximum crop yield [6], thus combatting the food crisis of 1960 [7,8]. Between 1961 and 2000, crop performance doubled and food production per capita increased by $24 \%$. Between 1960 and 2010, the land area allocated for the production of food crops rose $12 \%[6,9]$, and total food production (cereals) increased 240\% from 1961 to 2017 [10]. Undoubtedly, agriculture is a key driver of economic development [11,12]; however, this "evolution" in the agricultural sector has caused substantial and alarming environmental impacts [1,13-15]. Indeed, transformation of the traditional intensive and extensive agricultural system is an urgent priority [16,17]. Thus, the 2030 Agenda was approved in 2015, containing 17 Sustainable Development Goals (SDG) and 169 objectives [18,19], among which is the aim to "End hunger, achieve food security and improved nutrition, and promote sustainabile agriculture". Based on this goal, more than 30 countries have instated public policies that promote agroecology [20], with an approach focused on integrated resource management and the reduction and substitution of non-renewable inputs [21].

\subsection{Family Farming, Circular Economy and Bioeconomy-Priorities for SDG}

Family farms have been the primary means of food production worldwide, and they belong to a sector that has created the highest number of jobs, therefore making small growers key agents of economic growth and development of countries [22-26]. The United Nations Decade of Family Farming 2019-2028 Global Action Plan, released in 2017 [24,27], reaffirms the commitment of world leaders to address the significant challenges of the 2030 Agenda alongside allies such as small farmers, who have demonstrated their capacity and potential to achieve local food systems that are both sustainable and resilient [24]. Sustainable agriculture should reflect the principles of the circular economy in all stages of its processes, from initial production to final consumption and, finally, efficient and appropriate waste management [28]. Thus, the circular economy proposes a model of efficient resource management which prioritises "closing the loop" [29], thereby avoiding losses in value of materials and products and prolonging their life by incorporating waste into production processes [19,30-32]. Since 2015, the EU has made progress with its Action Plan for the Circular Economy. One of the main objectives is to promote the use of secondary raw materials [33,34].

As for the Sustainable Bioeconomy Strategy for Europe, adopted by the EU in 2012 [35] and updated in 2018 [12], it is part of the EU Horizon 2020 programme of 2014 [28,36]. What is more, this strategy is a political priority, which encompasses all sectors of the economy, including agriculture as one of the most important biological industries in the primary sector for its generation of biomass [37-40]. The key elements of the bioeconomy are circularity and the use of renewable biological resources, such as plant and animal biomass [41]. The reduction of fossil fuel use, recycling of materials and the recovery of waste to obtain by-products (bioenergy, biofuel, chemical products) [42] are essential aspects for the bioeconomy to become aligned with sustainable development objectives [43-45]. The bioeconomy, as an economic-production model, provides innovative alternatives for achieving the main socio-economic and environmental challenges of the 2030 Agenda, such as the increase in agricultural production to meet the needs of a world population forecast to reach 10,000 million by 2050 [15]. What is more, all activity must be carried out using fewer resources, while also preserving the environment and reducing $\mathrm{CO}_{2}$ emissions $[41,46,47]$. In this way, greenhouse gas emissions could be reduced $50 \%$ by the year 2050, if there is an increase in the use of biomass and waste to obtain energy $[48,49]$. Since 2015, implementation of the bioeoconomy has become more widespread as a general strategy for key sustainability policies. However, its definition and approach are quite varied, considering that in different countries this model is referred to as "sustainable and circular bioeconomy", "biologization of the economy" and "circular bioeconomy" [47,50].

\subsection{Protected Horticulture and Agricultural Waste Biomass as the Basis of the Bioeconomy}

Since 2003, the Food and Agricultural Organization (FAO) has promoted sustainable protected agriculture as an alternative for adaptation to climate change [51]. Similarly, the European Innovation 
Partnership for Agricultural Productivity and Sustainability (EIP-AGRI) has made efforts to promote "Circular Horticulture", with the aim of fostering good practices that will increase circularity in protected horticulture, given the substantial increase in greenhouses crops $(405,000$ ha), mainly in countries such as Spain, France, Greece, Italy and the Netherlands [52-54]. As for Spain, it boasts the largest land cover in Europe, with 50,365 ha of greenhouses [55], most of which are distributed along its southern coast. The protected crop system is characterised by its high efficiency in the use of resources (water, soil) and high productivity per land unit year-round, which can reach up to 15 times more than that of open-air agriculture systems [51,56,57]. However, it also generates considerable amounts of plant waste, most of which is either not managed properly or not exploited as a raw material for other production processes, meaning the majority of this waste is disposed of in landfills [54]. In the province of Almeria (Spain), the protected crop system began in 1960 [58,59], always following a model of small family farms, which was the main driver of the demographic and socio-economic development of this region [60-62].

Almeria has the highest concentration of greenhouses in the world [60], with 31,614 ha in 2018 [63], and its horticultural production is primarily organised into two growing seasons, which generates a larger crop-growing surface $[64,65]$. This system obtains a high production level which, in turn, produces a high concentration of waste biomass at different times of the year, complicating suitable management processes $[66,67]$. Currently, in the province of Almeria there is no integrated management system for greenhouse plant waste which promotes its use among growers and contributes to preventing environmental impacts $[53,66]$. Therefore, it is crucial that growers be guided in order to strengthen their capacities to implement good practices for the efficient use and sustainable management of resources based on the circular economy and the bioeconomy $[15,54,68]$. One sustainable practice is the reutilisation and the exploitation in situ of waste biomass, contributing to cost savings through the elimination and reduction of dependence on new inputs [51,53,69].

Based on this scenario, the socio-economic importance of Almeria's intensive agricultural model, both in terms of its production volume and economic value, must bear in mind the need to produce within a sustainable model, in accordance with the SDGs and based on the circular economy and the bioeconomy. Thus, this study proposes the following objectives.

1. Characterise the main protected horticultural crops in the province of Almeria and estimate the production of greenhouse waste biomass.

2. Identify the current management strategies for agricultural waste biomass from greenhouses, as well as the policies and regulatory tools responsible for its integrated management.

3. Analyse the possible alternatives for the exploitation of waste biomass and the opportunities for growers.

4. Conduct an economic assessment of self-management of agricultural waste to analyse the feasibility of its implementation as a sustainability strategy.

\section{Materials and Methods}

\subsection{General Stages of the Process}

Conducting the present study involved the compilation, validation, processing and analysis of information obtained primarily from studies, technical reports and statistics from public and private institutions with authority on and/or connections with the subject, from the international to the local level. With the aim of obtaining accurate and updated information, data was directly requested (by both e-mail and phone) from regional and local government agencies that were prioritised as key agents based on their legal capacity. Similarly, face-to-face and telephone interviews were carried out with some of the department heads of regional and local public entities, who supplied essential information to the semi-structured questionnaire designed for said purpose. The review of research literature on the evaluation of agricultural waste biomass was obtained from the Scopus and Web of Science (WOS) databases. Figure 1 displays the main stages of the elaboration process of the present study. 


\subsection{Specific Methods Developed by Each Objective}

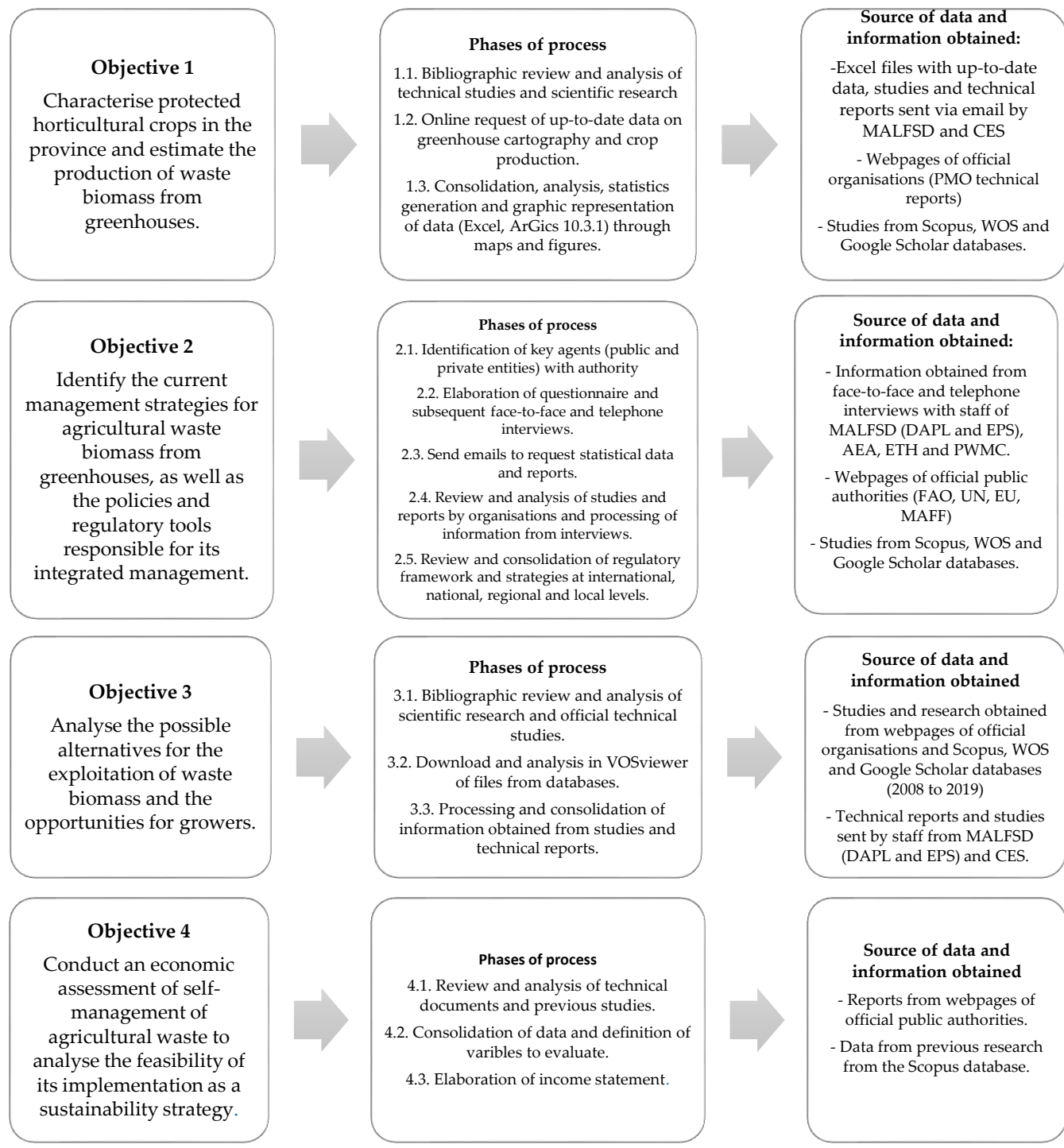

Figure 1. Stages of the study elaboration process by objective. MALFSD: Ministry of Agriculture, Livestock, Fisheries and Sustainable Development of the Regional Government of Andalusia, DAPL: Department of Agricultural Production and Livestock, EPS: Environmental Protection Service, PMO: Prices and Markets Observatory, AEA: Andalusian Energy Agency, CES: Cajamar Experimental Station, PWMC: Plant Waste Management Companies, ETH: El Ejido Town Hall, FAO: Food and Agriculture Organization of the United Nations, UN: United Nations, EU: European Union, MAFF: Ministry of Agriculture, Fisheries and Food.

\subsection{Additional Specifications for Objective 4}

Upon presenting data, from the income statement of a particular farm dedicated to intensive agriculture in the province of Almeria, it was necessary to consider the real revenues and expenses structure proposed in an investigation conducted by the Fundación Finca Experimental Universidad de Almería-Anecoop (University of Almeria-Anecoop Experimental Farm Foundation), as well as data from a field study carried out by Toresano and Camacho for Agroseguros, S.A., Spain [65]. Both documents have recently been published to highlight the advantage of expanding the range of horticultural products in Almeria by incorporating the production and commercialisation of certain subtropical crops [65].

During the elaboration of the income statement, the following characteristics of the farm itself, the agricultural waste management model and the market conditions were taken into consideration: 
- All calculations were adapted to a farm with a land area of 1 ha, with an Almeria-type "backbone" greenhouse measuring 6 metres ridge height, 5 metres gutter height (amagado) and 4.70 metres wall height. The remaining production facilities included an irrigation system, water collection reservoirs and a climate control system-common for the production model in Almeria, as is the cost structure presented (variable and fixed) [60].

- The production and prices of tomato crop were estimated based on official documentation published in the Annual Report of the Ministry of Agriculture, Fisheries and Rural Development for the 2017/2018 season [58].

- The relative costs of agricultural waste management are assigned according to the method chosen by the grower and following the cost calculation proposed in Torres Nieto [70]. Two options are presented for managing agricultural waste:

o Without self-management of waste, that is, the removal and transportation of plant waste to an external company specialised in agricultural waste management. Thus, the only additional costs involved are transport expenses and recycling taxes due.

o Self-management of waste, that is, the grower undertakes all tasks related to cleaning and processing and the ultimate application of resulting green fertiliser on their farm.

\section{Results and Discussion}

\subsection{Characterisation of the Intensive Protected Horticultural System in Almeria}

\subsubsection{Evolution of Greenhouse and Crop Land Cover}

According to historical registers supplied by the Ministry of Agriculture, Fisheries and Sustainable Development of the Regional Government of Andalusia, greenhouse land cover in the province of Almeria rose from 30 hectares in 1969 to 31,614 in 2018, and currently represents more than 70\% of all greenhouse cover in the Autonomous Region of Andalusia [63,64] (Figure 2). As of 1977, protected crop land began growing exponentially, increasing from 3,440 ha to 27,725 ha in 1999 . Between the years 2000 (26,531 ha) and 2013 (26,884 ha), there was less significant growth; however, following this period, greenhouse land cover in the province of Almeria increased by 14.5\% between 2014 (27,598 ha) and 2018. As for farming activity, greenhouse production in the province of Almeria is primarily organised into two growing cycles per year, generating a larger crop-growing surface $[64,65]$.

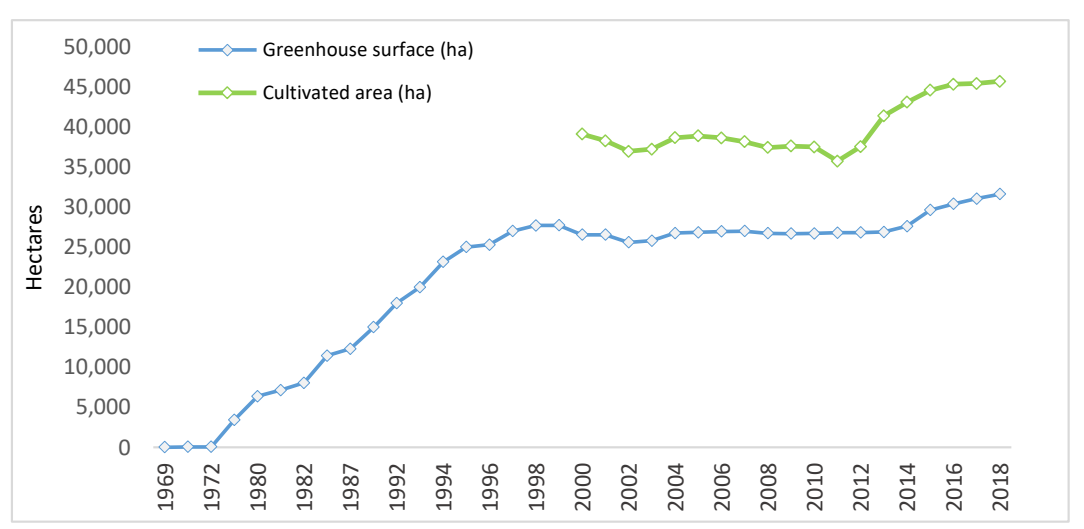

Figure 2. Evolution of physical land area and greenhouse crop area. Authors' own elaboration based on data supplied by the Ministry of Livestock, Fisheries and Sustainable Development of the Regional Government of Andalusia.

In 2000, this land area reached 39,094 ha, and the following year, it decreased to 35,726 ha. As of 2012, it continued to increase again until 2018, when the land area reached 45,680 ha. (Figure 1). In the last 18 years, the physical land area of greenhouses has risen by $16 \%$, and actual crop land use has risen by $14 \%$. 


\subsubsection{Distribution of Greenhouse Cover by Farming Areas and Towns}

In 2018, cartography elaborated by the Ministry of Agriculture, Fisheries and Sustainable Development of the Regional Government of Andalusia reflected that the greenhouse land area in the province of Almeria was fundamentally distributed among six districts: Campo de Dalías, with the largest cover, 21,545 ha (68\%), Campo de Nijar, with 8748 ha (23\%), Bajo Almanzora, with 686 ha, Campo de Tabernas, with 326 ha, Río Nacimiento, with 243 ha and Alto Andarax, with 66 ha (Figure 3).

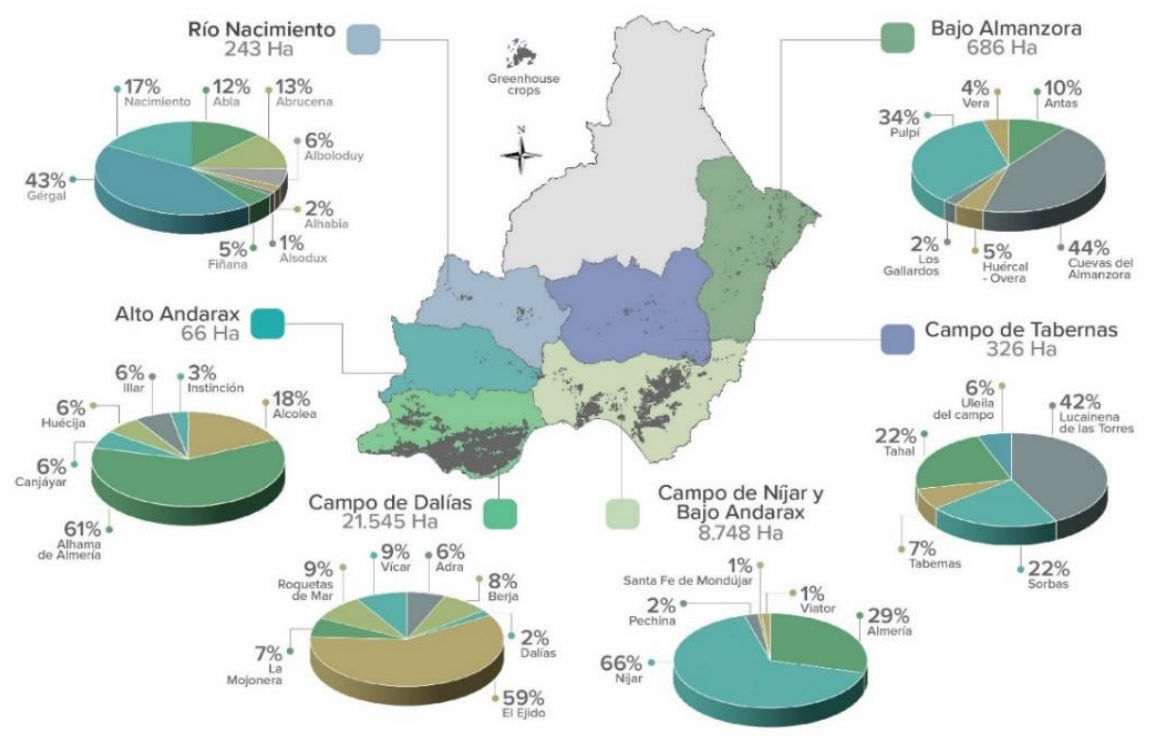

Figure 3. Distribution of greenhouse land area by farming areas and towns. Authors' own elaboration based on data from the Ministry of Agriculture, Fisheries and Sustainable Development of the Regional Government of Andalusia.

The town of El Ejido, with 12,756 ha, covers the largest area of greenhouses in the province (40\%), followed by the town of Nijar, with 5744 ha, and Almeria, with 2525 ha. These three towns represent $67 \%$ of the total land in the province. The towns with the least greenhouse cover are Las Tres Villas (1 ha), Huércal de Almería (2 ha) and Instinción (2 ha) [63].

\subsubsection{Main Crops and Evolution of Horticultural Production}

Table 1 displays the main protected horticultural crops in the province of Almeria and their land area and production in the year 2018.

Table 1. Land area and production of the main crops in the province of Almeria in the year 2018.

\begin{tabular}{ccccccccc}
\hline & Tomato & Pepper & Courgette & Watermelon & Cucumber & Aubergine & Melon & Green beans \\
\hline Land area (ha) & 10,380 & 10,181 & 7755 & 7797 & 5099 & 2150 & 1808 & 510 \\
Production (t/year) & 992,669 & 732,118 & 452,035 & 397,832 & 443,604 & 181,130 & 73,394 & 9819 \\
\hline
\end{tabular}

Source: Authors' own elaboration based on data from Ministry of Livestock, Fisheries and Sustainable Development of the Regional Government of Andalusia.

Between 2002 and 2018, the most important crops in Almeria were tomato, pepper, courgette and watermelon, as they accounted for the largest land area and the highest production (Figure 4a). Furthermore, in $2018,45 \%$ of vegetable crop land was devoted to the production of tomato and pepper, which generated $53 \%$ of total production in the province $(3,282,601 \mathrm{t})$. In the case of these two crops, which generally have a longer cycle [67], land area has experienced significant annual growth, with tomato increasing from 7392 ha in 2002 to 10,380 ha in 2018. As for pepper, it rose from 8.550 ha in 2002 to 10,181 in 2018. During this time, production increased and decreased for both crops from year to year, though some of these changes were not significant. Indeed, from 2002 to 2018, production increased by $19 \%$ and by $26 \%$ for tomato and pepper, 
respectively. During this same period, crop land area rose seven percentage points in the case of tomato, with respect to the land devoted to pepper. As for other crops, between 2002 and 2018, aubergine, green bean, melon and cucumber represented $24 \%$ of total fruit and vegetable production. In 2018, melon and green bean registered their lowest yields, accounting for only $3 \%$ of all crops and $5 \%$ of total land area. In the case of these two crops, both land area and production significantly decreased [65].

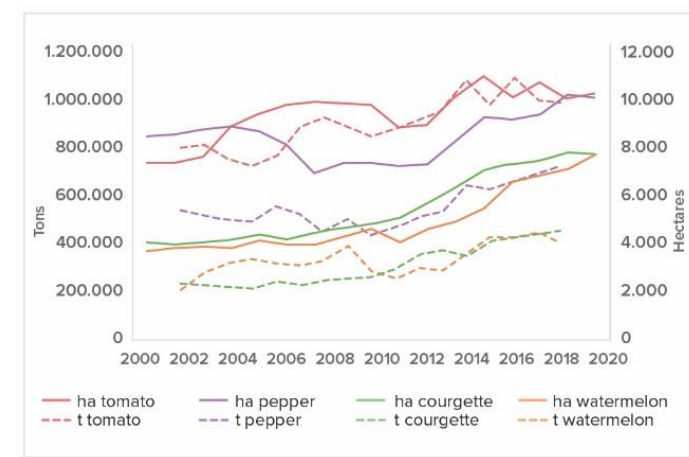

(a)

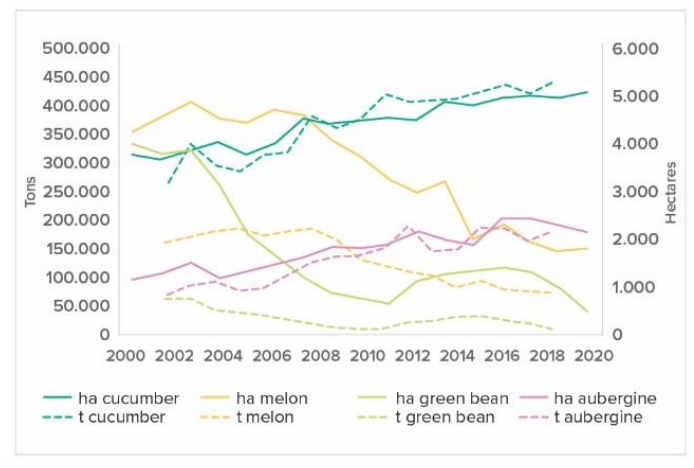

(b)

Figure 4. Evolution of land area and crop production: (a) Tomato, watermelon, pepper and courgette crops; (b) aubergine, green bean, cucumber and melon crops. Source: Authors' own elaboration based on data from the Ministry of Livestock, Fisheries and Sustainable Development of the Regional Government of Andalusia.

In the case of green bean, this crop fell from 4,030 to 510 farmed hectares, and production dropped $85 \%$ from 2002 to 2018 . As for melon, land area decreased from 4,278 to 1,808 hectares, and production reduced by $55 \%$ during the same period (Figure $4 \mathrm{~b}$ ).

In addition, Honoré et al. [71] present profitability data of the most representative crops in the province of Almeria, arranged in five production alternatives, over a period of 30 months (February 2016 to July 2018).

\subsection{Policies, Strategies and Regulatory and Financial Tools Promoting Integrated Management of Agricultural Waste Biomass}

The 2030 Agenda, which had been in development and taking shape since the United Nations Conference on the Human Environment in 1972 [59], is the most important global action plan, constituting the guide by which countries can advance towards the implementation of a sustainable development model. Figure 5 indicates the four objectives of this universal plan, which have also been the primary legal basis for policies, regulatory tools, strategies, programmes and other related mechanisms in force that have been issued and adopted by the EU and Spain to support the transition towards a circular economy and bioeconomy. This figure presents the general framework of these policies and highlights tools related to the handling, exploitation and recovery of agricultural waste biomass. EU Directive 2018/2001 of the European Parlament and of the Council of 11 December 2018, on the promotion of the use of energy from renewable resources, defines agricultural biomass as the biodegradable fraction of products, waste and residues from biological origin from agriculture [72]. According to Directive 2008/98/CE on waste, modified by EU Directive 2018/851 and the Communication from the Commission to the Council and the European Parliament on the Interpretative Communication on waste and by-products (COM), a by-product is a production residue that is not waste [51]. In this sense, agricultural waste biomass is only considered a by-product if it is produced as part of a production process, is subjected to transformation by normal industrial practice and its final use is legal [73,74].

In 2017, the Spanish Ministry of Agriculture, Fisheries, Food and the Environment issued the official procedure for identifying by-products [71]. Since 2018, this entity has approved various orders related to the classification of residues and the declaration of materials as by-products. The transposition of Directive 2008/98/CE to Spanish judicial code was carried out via Law 22 of 2011 on "waste and 
contaminated soils", modified by Law 5/2013 [75,76]. This law adopts the European classification and list of waste (2000/532/CE Decision Commission), which catalogues waste from primary production, horticulture, especially plant material waste, as non-hazardous [77]. Similarly, Law 22 of 2011 includes, among recovery operations, "the recycling or recovery of organic substances not utilized as solvents, including composting and other biological transformation processes" (Order MAM/304/2002). Regarding legal liability, this law declares that those who produce products have responsibilities and obligations in relation to the prevention and management of the waste they generate [75]. As for other legal matters, the EU considers that organic agriculture contributes to achieving environmental objectives (Regulation CE No. 834/2007) [78]. For this reason, it has emphasised the need for a new regulatory framework that facilitates the production and commercialisation of fertilizers manufactured using secondary raw materials, such as agricultural by-products [33,79]. In 2018, the reform of the Common Agricultural Policy (CAP) was presented [80]. This modified document prioritised the environment and climate and incorporated the bioeconomy as a specific objective, for which funds would be allocated primarily to make advances in research and innovation-two key elements in the circular economy model [81]. Regulation No. 1305/2013 of the European Parliament and Council establishes the aid for rural development through the European Agricultural Fund for Urban Development (EAFRD) [82]. Thus, one of the Strategic Themes (ST) of the Common Strategic Framework (CSF) [83] is to "Preserve and protect the environment and promote the efficiency of resources".

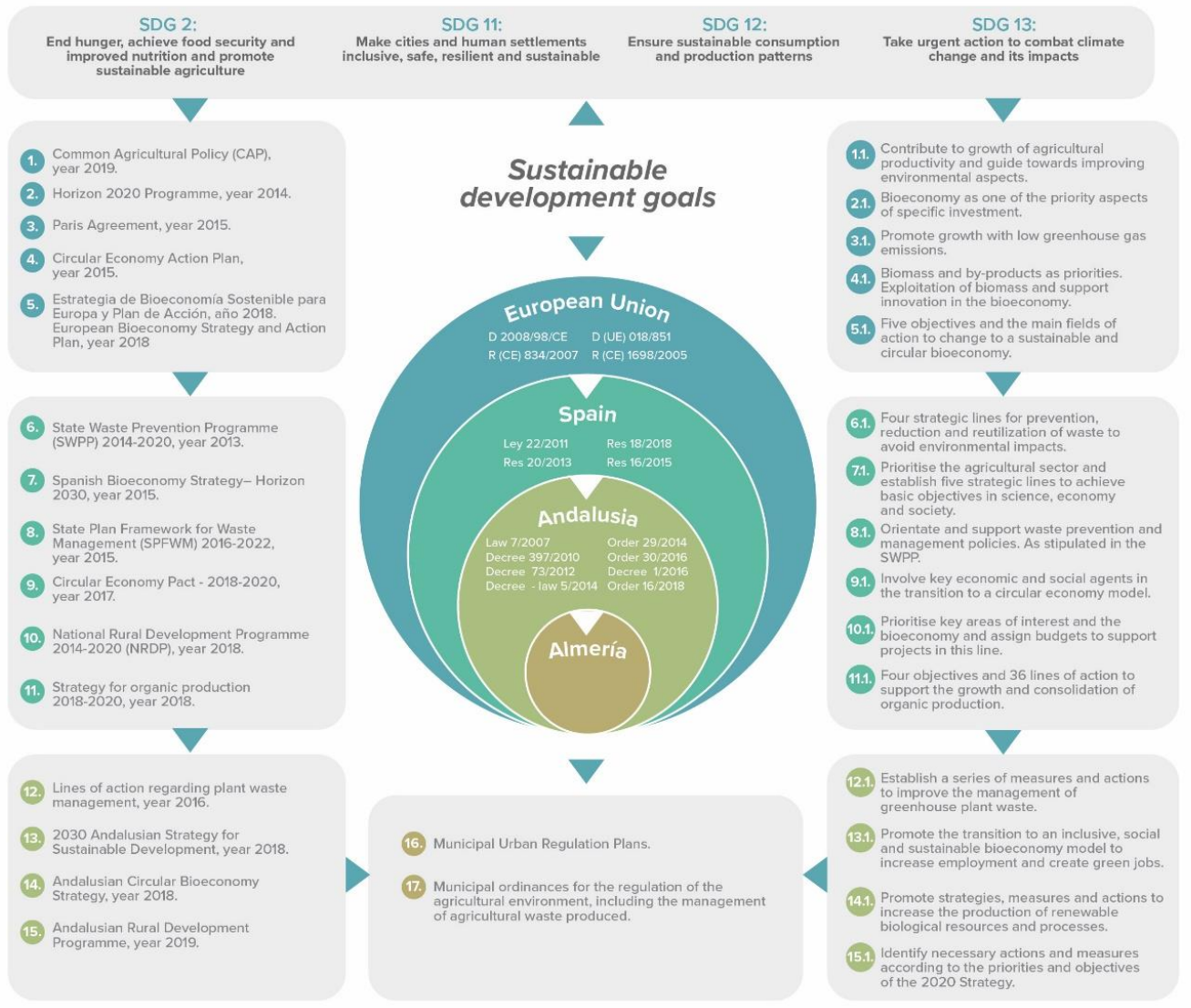

Figure 5. Policies framework, regulatory tools and strategies that promote integrated management of agricultural waste biomass. D: Directive; R: Regulation; Res: Resolution. Source: Authors' own elaboration.

The Horizon 2020 Programme is also one of the initiatives of the EU which, through Structural Funds and European Investment (EIE), has contributed substantial investments to research and innovation to carry out many of the key measures of the Circular Economy Action Plan and the European Bioeconomy Strategy $[28,84,85]$. Based on EU Regulation No. 1305/2013, the Spanish Government presented the National 
Programme for Rural Development 2014-2020 (PNDR) [86], which details the actions that will boost agrifood and forestry innovation in rural areas. This programme prioritises aid for environmental projects and practices and for the sustainable supply of biomass. Among its main points is Focus Area 5C: "Facilitate the supply and use of renewable energy sources, by-products, waste, residues and other non-food raw materials to promote the development of the bioeconomy". Within the framework of this programme, and through the Resolution of 18/2018 of the Spanish Agrarian Guarantee Fund (FEGA, in Spanish), aid was made available to grant subsidies for innovation projects related to productivity and agricultural sustainability, as stipulated in Focus Area 5C [87]. Additionally, the Spanish Government has promoted other plans, programmes and strategies [88-92], and it is currently elaborating Spain's National 2030 Circular Economy Strategy, whose first draft was presented at the end of 2018.

\subsection{Characterization and Estimation of Waste Biomass Production from Greenhouses in the Province of Almeria}

Plant waste consists mainly of roots, stems and leaves which come from pruning and maintenance, as well as the final removal of plants at the end of the growing cycle [93]. Any produce that cannot be sold, which is removed directly at the growing site, generates less volume but accounts for $25 \%$ of the total. The production of these types of waste varies from crop to crop depending on the size of the plant, its planting density and the different farming practices utilised (form pruning, production pruning or regenerative pruning), among others [94,95]. The production cycles of the different crops determine the period in which the largest volume of waste biomass will be generated, which normally corresponds to the months of May and June. This period is when spring crops and long-cycle crops (mainly cucumber, pepper and tomato) finish their growing stage, generating approximately $75 \%$ of plant waste. The end of autumn crops, during the months of January and February, generate the remaining $25 \%$. The predominant crops in this second growing cycle are tomato, pepper, green bean, watermelon and melon [67].

One of the main characteristics of this organic biodegradable material generated in greenhouses is its high water content $(60 \%)$ and its low weight to volume ratio $[50,66]$. However, this waste is typically mixed with non-biodegradable clips and raffia $[95,96]$ used for tutoring plants, which makes its direct use non-viable and increases the costs of its exploitation as a by-product [94,97]. The estimation of the annual average production of waste biomass per crop was calculated by applying ratios of biomass generated by each crop type, previously determined by past studies $[94,97,98]$, to the average crop cover between 2014 and 2018. Thus, the agricultural waste biomass produced by horticulture in Almeria is estimated at 1,370,743 t annually. Figure 6 indicates the average land area of each crop and the corresponding annual amounts of waste biomass. Tomato farming, with $525,901 \mathrm{t}$, and pepper, with $271,460 t$, generate more than $50 \%$ of the waste biomass. Green bean $(25,530 t)$ and aubergine $(60,761 \mathrm{t})$ supply only $6 \%$. Taking into consideration the land area and average production of the main long-cycle crops (tomato and pepper), a greenhouse can produce between 84 and $147 \mathrm{t} / \mathrm{ha}$ annually.

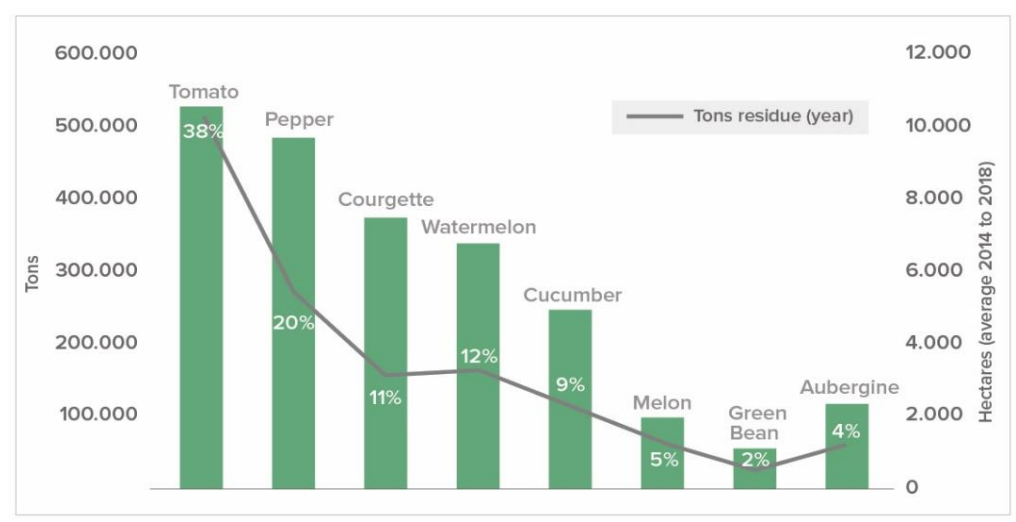

Figure 6. Average land area per crop and average annual production of waste biomass per crop. Souce: Authors' own elaboration based on data from the Ministry of Livestock, Fisheries and Sustainable Development of the Regional Government of Andalusia and other studies [94,97,98]. 


\subsection{Current Management Strategies for Agricultural Waste Biomass from Greenhouses: The Case} of the Province of Almeria

In terms of waste management, the agricultural waste biomass generated by greenhouses has posed serious problems for the province of Almeria, primarily due to the significant increase in the generation of this waste and the inadequate disposal practices followed by growers. In 2001, poor management of this waste caused a health crisis as a result of the accumulation of plant waste in the Almeria region [62,94]. Although until that point in time a great deal of said waste was destined for animal feed or used as a soil input, the enormous amounts of waste being generated eventually brought about the crisis, revealing the need to implement a suitable agricultural waste management system in the province. Since then, the corresponding public authorities have financed massive waste collection initiatives and promoted the issuing and signing of agreements, town ordenances and rural cleanliness plans [94,99] as a general strategy to improve integrated agricultural waste management [69].

At present, the province of Almeria has more than ten authorised plants for the treatment and recovery of agricultural plant waste, six of which are central plants that receive most of the plant residues generated in greenhouses. In "Campo de Dalías", the area with the highest greenhouse land area, $81 \%$ of farms (from a sample of 284 farms) deposit their waste at authorised plants. As for the "Campo de Nijar and Bajo Andarax" area, the percentage is 67\% (from a sample of 374 farms).

As for other programmes, $15 \%$ of farms in "Campo de Dalias" conduct their own exploitation and self-management processes for plant waste. In these cases, $98 \%$ of this material is used for green fertilizer and, to a lesser extent, for composting (2\%). Furthermore, $3 \%$ of the waste in this area is classified as by-products destined for animal feed.

In the case of the "Campo de Nijar and Bajo Andarax" area, self-management of plant waste is more common, practiced by $22 \%$ of farms. Of these, only $6 \%$ use the waste for composting or "vermicomposting" (5\%), and only 1\% use it as green fertilizer [100-102]. Authorised controlled burning is also one of the treatment alternatives for such waste, although it is becoming less common [66].

Despite the good practices mentioned in the region, according to information provided by the Ministry of Livestock, Fisheries and Sustainable Development of the Regional Government of Andalusia, there is currently no consolidated agricultural biomass management model. Nevertheless, there are indications that inappropriate fertilization and burning of agricultural waste have decreased in the Almeria farming region, which is demonstrated by the reduction in the number of fines for such practices. Similarly, the regional government indicates that the use of green fertilizers is associated with those greenhouses that practice organic farming [66]. However, there is still no register for farms that conduct good practices of agricultural waste treatment, nor any register of the amount of plant waste that is generated by farms on average. Andalusia is the Spanish Autonomous Region with the largest crop area devoted to organic production and Almería is the second smallest province in terms of size [103,104]; yet, in 2017, there were 3,065 operators registered as organic growers [104].

According to data supplied by the Local Almeria Delegation of the Ministry of Livestock, Fisheries and Sustainable Development of the Regional Government of Andalusia, in 2018, under the framework of the public call issued by Order 16/2018 for subsidies through Measure 10: Agri-environment and Climate, and Measure 11: Organic Agriculture, aid was allocated for 600 hectares, that is, approximately 300 growers in the province of Almeria [105,106]. These growers applied for this subsidy to implement practices of self-management of agricultural waste biomass on their land, mainly for green fertilizer production. Despite this initiative, activities associated with self-management of waste (green fertilizer and compost production) are quite scarce in the province of Almeria [66], demonstrating a need to evaluate the main causes that have restricted the development of these alternatives.

The main, a priori reasons for the deficient development of good practices in waste biomass management include the following:

- $\quad$ Regulatory frameworks, featuring administrative and technical demands that make it difficult for growers to comply with requisites and to implement recovery systems [69].

- Complex administrative processes and delays in the issuing of aid and/or authorisations [107]. 
- $\quad$ Lack of coordination between the policies and regulatory tools of public authorities responsible for waste managment and inspection and control processes [69].

- $\quad$ Mixed composition of crop waste, making treatment processes more complicated and expensive due to the presence of non-biodegradable materials [94,97].

- $\quad$ Restrictions on the space required to carry out compost production [66,69].

- Incompatability between the decomposition times of plant waste and the scheduled planting of short-cycle crops [66,69].

- $\quad$ Financial obstacles and economic risks related to the implementation of new practices [108].

- Ignorance of international, national and regional policies and directives that promote and favour the adoption of sustainable agricultural practices.

\subsection{Alternatives for the Exploitation of Waste Biomass from Greenhouses and Opportunities for Growers}

The broad strategic and regulatory framework has recently been strengthened to promote, prioritise and facilitate the recovery of agricultural waste biomass. This action represents an important advance contributing to the elimination of the obstacles and restrictions which growers had been facing, thereby creating a great opportunity for the implementation of techniques for self-management of crop waste. All the strategies mentioned previously, included in the framework of the bioeconomy strategy, combined with concerns about more expensive processes linked to efficient management of crop waste [61,95], and the latter's immense recycling potential [69], for many years (2008 to 2019, according to Scopus data) have created a need for research investigations and specific studies on the analysis of the properties of agricultural waste biomass from greenhouses in the province of Almeria, as well as the most viable alternatives for its exploitation and recovery. Results of these studies indicate that some crops, such as pepper, tomato and aubergine, have a higher lignin and cellulose content than others, for example, watermelon, melon and courgette [109,110]. Given the relationship between the contents of these components and their energy properties, the use of all plant waste could be limited to the production of energy.

However, there has been research that highlights the importance of waste from tomato and pepper crops as a new source of renewable energy [111,112]. Although their high moisture content reduces their caloric value [113] and makes them inefficient for biofuel production and gasification processes $[61,114]$, some investigations suggest that combined heating and carbonic enrichment systems for greenhouses could be implemented by exploiting the combustion of these materials $[115,116]$. Perhaps, this alternative could also justify the production of other high added value bioproducts [61] using this waste material, such as the manufacturing of briquettes for household heating systems [117] and as a by-product for animal feed [118].

In practice, a great deal of the scientific literature analysed focuses on the recycling of plant waste from horticultural crops in Almeria, more so than on energy recovery [70]. Some of these investigations prioritise the implementation of compost production plants as an alternative to greenhouse waste management $[94,96,119]$. Other studies analysed, and technical documents by government agencies, highlight the main benefits associated with the production of compost and its use as an organic amendment in greenhouses. The benefits they cite are the following:

- Increase in the percentage of larger-diameter particles, reduction in apparent density and increase in effective organic matter content that improves the fertility of soil $[53,64,67,120-124]$ and provides necessary nutrients to crops.

- $\quad$ Control and reduction of diseases caused by pathogens transmitted through soil [70,120].

- Carbon storing, for a longer period of time, which could help to reduce $\mathrm{CO}_{2}$ emissions and mitigate global warming [121,122].

These studies highlight several possible limitations with respect to using compost as an organic amendment. These limitations include a reduction in water use efficiency due to increased porosity and reduced soil water retention [53,123], increased electrical conductivity [51,124] and extended duration 
of decomposition and liberation of nutrients supplied to soil $[53,121]$. Therefore, these variables must be adapted to the needs of each crop and the soil characteristics where they are grown $[123,124]$. It is also necessary to consider that the physical-chemical properties of the compost obtained will be determined by the waste that is utilised, the treatment methods implemented and the stage of compost maturity, which, in turn, influences the mobility and availability of nitrogen in soil [53]. Similarly, so as to avoid risks of pathogens and pests, certain aspects must be properly regulated, such as moisture, temperature and the transformation and processing time of waste [53]. The selection of a suitable and safe process, by following technical guidelines and regulations on the subject, will guarantee the production of a good quality compost, free of pathogens and contaminant elements [69].

Similarly, specific emphasis is placed on the importance of plant waste being free of any plastic waste or materials in order to facilitate the transformation process, avoid contaminant emissions and achieve the transition towards a more ecological agricultural system, with lower agrochemical content [117]. Given the characteristics of the farms in the province of Almeria, the lack of space in some greenhouses could limit the production of compost in these facilities. Similarly, the requirements established by the regulation which governs the production and commercialisation of fertilizers elaborated using secondary raw materials, such as agricultural by-products, implies additional obstacles for growers [66]. Nevertheless, all the aspects analysed lead to the conclusion that the recovery of agricultural waste biomass from greenhouses is a necessity and represents a great opportunity, especially for growers, primarily for the following reasons:

$\checkmark \quad$ It guides them towards adopting policies and global action plans related to sustainable development.

$\checkmark \quad$ It is one of the main activities of organic agriculture, which is also one of the main objectives of the circular bioeconomy strategy.

$\checkmark \quad$ It is a priority issue for governments, which offers the possibility of gaining access to aid and subsidies that promote sustainable agriculture.

$\checkmark \quad$ It responds to the growing demand among consumers who prefer quality agricultural products obtained by means of environmentally friendly techniques and processes.

$\checkmark \quad$ It contributes to the recovery of agricultural waste biomass, which, in economic terms, reduces costs of inputs and raw materials.

$\checkmark \quad$ It minimises the production of waste, saving costs of transporting and managing the treatment of waste, while also reducing the negative impact on the environment.

\subsection{Economic Assessment of Self-Management of Waste as a Transition towards Organic Fertilization}

Table 2 displays the comparison of the income statement of a farm dedicated to long-cycle tomato production-one of the most common crop combinations in the province of Almeria (tomato being the crop with the largest land area: 10,380 ha in 2018).

Table 2. Annual income statement for tomato crop. Impact of self-management of agricultural waste.

\begin{tabular}{|c|c|c|c|}
\hline \multirow[b]{2}{*}{$\begin{array}{c}\text { Comparison } \\
\text { Aug } 2017 \text { to July } 2018\end{array}$} & \multicolumn{3}{|c|}{ Tomate Crop } \\
\hline & $\begin{array}{c}\text { Without } \\
\text { Self-Management of } \\
\text { the Waste (1) }\end{array}$ & $\begin{array}{c}\text { With } \\
\text { Self-Management of } \\
\text { Waste (2) }\end{array}$ & $\underset{(1-2)}{\Delta}$ \\
\hline Total annual incomes $\left(\boldsymbol{f} \cdot \mathrm{ha}^{-1}\right)$ & \multicolumn{2}{|c|}{$131,498 € €$} & $-€$ \\
\hline Production $\left(\mathrm{kg} \cdot \mathrm{ha}^{-1}\right)$ & \multicolumn{2}{|c|}{197,000} & $-€$ \\
\hline Average price $\left(€ \cdot \mathrm{kg}^{-1}\right)$ & \multicolumn{2}{|c|}{$0.668 €$} & $-€$ \\
\hline Total variable cost $(\boldsymbol{\epsilon})$ & $83,960 €$ & $83,345 €$ & $615 €$ \\
\hline Technical assessment $(€)$ & \multicolumn{2}{|c|}{$313 €$} & \\
\hline
\end{tabular}


Table 2. Cont.

\begin{tabular}{|c|c|c|c|}
\hline \multirow[b]{2}{*}{$\begin{array}{l}\text { Comparison } \\
\text { Aug } 2017 \text { to July } 2018\end{array}$} & \multicolumn{3}{|c|}{ Tomate Crop } \\
\hline & $\begin{array}{c}\text { Without } \\
\text { Self-Management of } \\
\text { the Waste (1) }\end{array}$ & $\begin{array}{c}\text { With } \\
\text { Self-Management of } \\
\text { Waste (2) }\end{array}$ & $\underset{(1-2)}{\Delta}$ \\
\hline Soil preparation $(€)$ & $1,674 €$ & $1,224 €$ & $450 €$ \\
\hline Fertilization $(€)$ & $2,223 €$ & $1,334 €$ & $889 €$ \\
\hline Covering and structure $(€)$ & \multicolumn{2}{|c|}{$4,799 €$} & $-€$ \\
\hline Seeds and seedling production $(€)$ & \multicolumn{2}{|c|}{$7,793 €$} & $-\epsilon$ \\
\hline Growing and development until 1st inflorescence $(€)$ & $10,791 €$ & $10,575 €$ & $216 €$ \\
\hline Flowering periods until 1st harvesting season $(€)$ & \multicolumn{2}{|c|}{$15,807 €$} & $-\epsilon$ \\
\hline $\begin{array}{l}\text { From the 1st harvesting season until the end of the } \\
\text { cultivation }(€)\end{array}$ & \multicolumn{2}{|c|}{$39,571 €$} & $-€$ \\
\hline \multicolumn{4}{|l|}{ Management of residual biomass } \\
\hline Transport and management in recycling plant & $990 €$ & $-\epsilon$ & $990 €$ \\
\hline Removal of raffia and shredding & $-\epsilon$ & $1030 €$ & $-1030 €$ \\
\hline Fertilizer management with plant residues & $-€$ & $900 €$ & $-900 €$ \\
\hline Total fixed costs $(€)$ & \multicolumn{2}{|c|}{$21,623 €$} & $-\epsilon$ \\
\hline Soil maintenance $(€)$ & \multicolumn{2}{|c|}{$2082 €$} & $-€$ \\
\hline Covering and structure $(€)$ & \multicolumn{2}{|c|}{$4168 €$} & $-€$ \\
\hline Energy and fixed supplies $(€)$ & \multicolumn{2}{|c|}{$1,646 €$} & $-€$ \\
\hline Insurance, management and financial services $(€)$ & \multicolumn{2}{|c|}{$3625 €$} & $-\epsilon$ \\
\hline Equipment and irrigation system $(€)$ & \multicolumn{2}{|c|}{$10,103 €$} & $-\epsilon$ \\
\hline Total expenses & $105,583 €$ & $104,968 €$ & $615 €$ \\
\hline Net profit (ha) & $25,914 €$ & $26,529 €$ & $-615 €$ \\
\hline
\end{tabular}

Source: Authors' own elaboration based on Toresano and Camacho, Honeré et al. [65], the Annual Report of the Ministry of Agriculture, Fisheries and Sustainable Development [58] and Torres Nieto [70].

Based on the results presented in Table 2, it is observed that self-management of waste from long-cycle tomato crop would generate a greater profit than the strategy of ceding waste management duties to a local recycling plant. More specifically, the profit increase is estimated at $615 €$ for the $2017 / 18$ season. Therefore, in as much as self-management of waste biomass generated on a farm entails new costs, such as the manual sorting of raffia and plastic and metallic materials, in addition to the cost overrun of processing waste on site, this alternative offers two fundamental advantages:

1. There is a decrease in the use of three key inputs: soil preparation cost, inorganic fertiliser and water, particularly in the phase lasting from planting to initial flowering. This result is in line with the findings of other studies, particularly those for tomato crop [125]. Concretely, the self-management of waste strategy means a saving of $450 € /$ ha in the cost of "Soil preparation", because part of these tasks are charged to the activities of the "Management of residual biomass ", i.e., "Removal of raffia and shredding" (+1030 $€ /$ ha) and "Fertilizer management with plant residues" (+900 $€ /$ ha). These new costs are according to the study by Torres Nieto [70], which estimates a total cost of $1,930 € /$ ha for a tomato crop. However, farmers who choose the self-management of the waste strategy do not assume the cost of transport to the recycling plant (+990 €/ha). In addition, farmers who prefer not to use the self-management of the waste strategy accept a higher cost of fertilization per hectare $(+889 € /$ ha) because the contribution of vegetable residues to the soil (with self-management of waste strategy) saves around $40 \%$ of the total fertilization costs. Moreover, the contribution of green biomass means a saving of $2 \%$ in the consumption of irrigation water, especially from "Growing and development until 1st inflorescence" (+216€/ha). This result is according to the data obtained by García-Raya et al. [125] for a tomato crop. 
2. Soil quality is improved through organic enriching, favouring a more eco-friendly agriculture in line with the current demands of consumers.

\section{Conclusions}

Almeria boasts a greenhouse land surface of 31,614 ha and an even larger crop-growing surface $(45,680 \mathrm{ha})$, thanks to the scheduling of two growing cycles per year. In the last 18 years the physical land area of greenhouses has risen $16 \%$ and actual crop land use has risen $14 \%$, respectively. These data make Almeria the province with the highest concentration of protected crop surface (greenhouses) in Spain and the world. The greenhouses in this region are mainly distributed among six districts and 37 towns; the district with the largest cover is the Campo de Dalías, with 21,545 ha (68\%), of which 12,756 ha are located in the town of El Ejido (40\%). The Alto Andarax district features the lowest number of greenhouses in the province (66 ha). The main protected horticultural crops in Almeria, from highest to lowest crop cover are tomato, pepper, courgette, watermelon, cucumber, aubergine, melon and green beans. The first four crops represent the largest crop surfaces and the highest production; these are generally long-cycle crops.

The high productivity of these farms, resulting from a combination of short- and long-cycle crops throughout the year, also generates a considerable amount of plant waste, comprised mainly of roots, stems, leaves and fruits from pruning, maintenance and the final removal of plants at the end of the growing cycle. The agricultural waste biomass produced by horticulture in Almeria is estimated at $1,370,743 \mathrm{t}$ annually, of which 515,901 $\mathrm{t}$ comes from tomato crops and 271,460 $\mathrm{t}$ from pepper. In other terms, these two crops supply more than $50 \%$ of the total waste biomass generated. Taking into consideration the land area and average production of these two long-cycle crops, a greenhouse can produce between 84 and $147 \mathrm{t} / \mathrm{ha}$ of plant waste annually.

For many years, managing waste biomass has posed serious problems for growers due to the accumulation of waste on their farms, mainly during summer months, when the long growing cycle ends ( $75 \%$ of waste). This situation also implies challenges for the local government, which must promptly modify its legal regulations to strictly avoid any negative impacts to the surrounding environment.

In practice, most biomass produced is transferred to external waste management companies and authorised recycling plants, for treatment and recovery processes. Another portion of this waste is used as a by-product for animal feed. To a lesser extent, this waste is self-managed by growers themselves on their land, green fertilizer being the primary alternative use of this material. Finally, a very small percentage is destined for compost production inside greenhouses. In the Campo de Nijar and Bajo Andarax growing district, self-management of plant waste is more common than in other areas and the use of green fertilizers is generally associated with those greenhouses that practice organic farming. Despite the high recovery potential of horticultural biomass and the different existing alternatives for the creation of added value of this biological resource, no integrated management system of greenhouse plant waste exists in the province of Almeria which would more actively promote waste recovery and contribute to the prevention of environmental impacts. Although some steps have been taken towards implementing such strategies, the incorporation of the bioeconomy as a specific objective, for the growth and evolution of the Almeria production system, continues to be a considerable challenge.

A great deal of research and numerous specific studies have analysed the properties of agricultural waste biomass from greenhouses in the province of Almeria. These works highlight its great potential in the production of energy, biofuels and bioproducts; its use in gasification and heating processes; and, especially, its recyclability and use in compost production-serving as an organic amendment in greenhouses. Furthermore, a vast strategic and regulatory framework (both nationally and internationally) has been reinforced to promote, prioritise and facilitate the recovery of agricultural waste biomass, which represents an important breakthrough and an opportunity to improve exploitation alternatives. After having estimated the potential of the waste biomass produced in the Almeria growing region (by crop type), it is observed that there are opportunities for exploitation, such as compost and green fertiliser, in the main crops grown in Almeria-namely tomato and pepper, for their 
land area and yield. In the specific case of tomato, this study presents an analysis of the advantages of self-management of agricultural waste by growers themselves. For this purpose, a farm was studied which is representative of the Almeria production model. It was demonstrated that the alternative of self-management of waste biomass is profitable. In addition, this process converts waste into a new nutrient and a new biofertiliser, thus helping to break the linearity of the traditional agricultural system and close the loop.

It is essential to conduct an in-depth analysis to determine the main factors that have limited the development of these alternatives, even in spite of subsidy programmes carried out in the province of Almeria. These obstacles and difficulties, which growers face, must be identified to understand why these individuals reject the implementation of techniques for the self-management of waste from their crops. By means of local strategies and regulations, recycling practices and techniques for the use of these plant by-products must be promoted to reduce the use of nitrogenated fertilizers, reduce the production of waste, save management costs and reduce negative environmental impact. Similarly, it is necessary to promote, at a local level, the establishment of small transformation facilities and support non-profit investments that help to achieve the environmental objectives corresponding to the new framework of the circular economy and the bioeconomy. Without question, this initiative must be conducted in parallel with an awareness campaign among growers in Almeria, in which the corresponding public authorities should also participate.

Finally, regarding a limitation of the present study, it must be stated that this research should be accompanied by a detailed study of the management models utilised for the waste biomass generated by intensive agriculture in Almeria. Such a field study should address the eight most important crops in southeast Spain and, at the same time, would update the data compiled and presented for the tomato crop in this research.

Author Contributions: Conceptualization, M.D.-A, L.J.B.-U. and F.C.-F.; methodology, L.J.B.-U., J.A.P.-Ú. and F.C.-F.; investigation, M.D.-A.; resources, F.C.-F. and M.D.-A.; writing-original draft preparation, M.D.-A, L.J.B.-U. and F.C.-F.; writing-review and editing, J.A.P.-Ú. and M.D.-A.; supervision, L.J.B.-U., J.A.P.-Ú. and F.C.-F. All authors have read and agreed to the published version of the manuscript.

Funding: This research was funded by the University of Almería (AGR-200), Almería, Spain.

Acknowledgments: The authors would like to thank the University of Almería for a predoctoral contract issued by the university in 2018 .

Conflicts of Interest: The authors declare no conflicts of interest.

\section{References}

1. FAO. Towards Zero Hunger 1945-2030; Food and Agriculture Organization of the United Nations: Rome, Italy, 2017.

2. Rivera-Ferre, M.G.; Ortega-Cerdà, M.; Baumgärtner, J. Rethinking study and management of agricultural systems for policy design. Sustainability 2013, 5, 3858. [CrossRef]

3. Food and Agriculture Organization of the United Nations. The international Code of Conduct for the Sustainable Use and Management of Fertilizers; Food and Agriculture Organization of the United Nations: Rome, Italy, 2019.

4. Food and Agriculture Organization of the United Nations. Organisation for Economic Cooperation and Development. Background Notes on Sustainable, Productive and Resilient Agro-Food Systems: Value Chains, Human Capital, and the 2030 Agenda; Organisation for Economic Cooperation and Development: Rome, Italy, 2019.

5. Food and Agriculture Organization of the United Nations. Food and Agriculture. Driving Action across the 2030 Agenda for Sustainable Development; Food and Agriculture Organization of the United Nations: Rome, Italy, 2017; Available online: http://www.fao.org/3/a-i7454e.pdf (accessed on 4 February 2020).

6. Food and Agriculture Organization of the United Nations. Status of the World's Soil Resources. Technical Summary; Food and Agriculture Organization of the United Nations: Rome, Italy, 2015.

7. Food and Agriculture Organization of the United Nations. The State of Food and Agriculture. Innovation in Family Farming; Food and Agriculture Organization of the United Nations: Rome, Italy, 2014. 
8. Food and Agriculture Organization of the United Nations. Strategic Work of FAO to Reduce Rural Poverty; Food and Agriculture Organization of the United Nations, 2017.

9. Aggarwal, P.; Vyas, S.; Thornton, P.; Campbell, B.M.; Kropff, M. Importance of considering technology growth in impact assessments of climate change on agriculture. Glob. Food Sec. 2019, 23, 41-48. [CrossRef]

10. United Nations-Intergovernmental Panel on Climate Change. Climate Change and Land: Summary for Policymakers. An IPCC Special Report on Climate Change, Desertification, Land Degradation, Sustainable Land Management, Food Security, and Greenhouse Gas Fluxes in Terrestrial Ecosystems. Summary for Policymakers. ipcc; 2019. Available online: https:/www.ipcc.ch/site/assets/uploads/2019/08/Edited-SPM_Approved_Microsite_ FINAL.pdf (accessed on 4 February 2020).

11. Lange, G.; Wodon, Q.; Carey, K. The Changing Wealth of Nations 2018: Building a Sustainable Future; Lange, G.-M., Wodon, Q., Carey, K., Eds.; The World Bank: Washington, DC, USA, 2018.

12. European Commission. A Sustainable Bioeconomy for Europe: Strengthening the Connection between Economy, Society and the Environment. Updated Bioeconomy Strategy; European Commission: Brussels, Belgium, 2018.

13. Aznar-Sánchez, J.; Belmonte-Ureña, L.; López-Serrano, M.; Velasco-Muñoz, J. Forest Ecosystem Services: An Analysis of Worldwide Research. Forests 2018, 9, 453. [CrossRef]

14. Aznar-Sánchez, J.A.; Velasco-Muñoz, J.F.; Belmonte-Ureña, L.J.; Manzano-Agugliaro, F. The worldwide research trends on water ecosystem services. Ecol. Indic. 2019, 99, 310-323. [CrossRef]

15. United Nations. The Sustainable Development Goals Report 2019; Jensen, L., Ed.; United Nations Publications: New York, NY, USA, 2019.

16. Binswanger, H.P.; Hazell, P.; McCalla, A. Agriculture and the Environment. Perspectives on Sustainable Rural Development; Lutz, E., Ed.; World Bank: Washington, DC, USA, 1998.

17. Ministerio de Agricultura y Pesca, A.y.M.A. Procedimiento Para la Declaración de Subproducto; Ministerio de Agricultura y Pesca, Alimientación y Medio Ambiente: Madrid, España, 2017.

18. European Commission. Investing in Sustainable Development. The EU at the forefront in implementing the Addis Ababa Action Agenda; European Commission: Brussels, Belgium, 2018.

19. Posición Común en Relación con la Iniciativa de la Comisión Europea Sobre "Modernización y Simplificación de la Política Agrícola Común. Available online: https://www.mapa.gob.es/es/pac/postura-reforma-pac/ posicioncomunconferenciasectorialabril2017_tcm30-379797.pdf (accessed on 5 February 2020).

20. United Nations Economic and Social Council. Report of the Team of Specialists on Innovation and Competitiveness Policies on its Tenth Session; United Nations Economic and Social Council: Geneva, Switzerland, 2017; Available online: https://www.unece.org/fileadmin/DAM/ceci/documents/2017/ICP/TOS-ICP/ECE.CECI.ICP. 2017.2.e.pdf (accessed on 5 February 2020).

21. FAO. Transforming Food and Agriculture to Achieve the SDGs.20 Interconnected Actions to Guide Decision-Makers; Food and Agriculture Organization of the United Nations: Rome, Italy, 2018.

22. DeLonge, M.S.; Miles, A.; Carlisle, L. Investing in the transition to sustainable agriculture. Environ. Sci. Policy 2016, 55, 266-273. [CrossRef]

23. Food and Agriculture Organization of the United Nations. International Fund for Agricultural Development United Nations Decade of Family Farming 2019-2028. Global Action Plan; Food and Agriculture Organization of the United Nations: Rome, Italy, 2019.

24. Food and Agriculture Organization of the United Nations. COAG/2010/6, Committee on Agriculture. Twenty-second Session, Rome, 16-19 June 2010. Policies and Institutions to Support Smallholder Agriculture; Food and Agriculture Organization of the United Nations: Rome, Italy, 2010.

25. Food and Agriculture Organization of the United Nations. FAO'S Work on Family Farming. Preparing for the Decade of Family Farming (2019-2028) to Achieve the SDGs; Food and Agriculture Organization of the United Nations: Rome, Italy, 2018.

26. Food and Agriculture Organization of the United Nations. Family Farmers. Feeding the World, Caring for the Earth; Food and Agriculture Organization of the United Nations: Rome, Italy, 2014.

27. Food and Agriculture Organization of the United Nations. International Fund for Agricultural Development (IFAD). Putting Family Farmers at the Centre to Achieve the SDGs; Food and Agriculture Organization of the United Nations: Rome, Italy, 2019.

28. Graziano da Silva, J. From Fome Zero to Zero Hunger: A Global Perspective; Food and Agriculture Organization of the United Nations: Rome, Italy, 2019. 
29. European Commission. EIP-AGRI Workshop "Opportunities for Agriculture and Forestry in the Circular Economy". Workshop Report 28-29 October 2015; European Commission: Brussels, Belgium, 2015.

30. Russo, I.; Confente, I.; Scarpi, D.; Hazen, B.T. From trash to treasure: The impact of consumer perception of bio-waste products in closed-loop supply chains. J. Clean. Prod. 2019, 218, 966-974. [CrossRef]

31. Blomsma, F.; Brennan, G. The Emergence of Circular Economy: A New Framing Around Prolonging Resource Productivity. J. Ind. Ecol. 2017, 21, 603-614. [CrossRef]

32. Molina-Moreno, V.; Leyva-Díaz, J.; Llorens-Montes, F.; Cortés-García, F. Design of Indicators of Circular Economy as Instruments for the Evaluation of Sustainability and Efficiency in Wastewater from Pig Farming Industry. Water 2017, 9, 653. [CrossRef]

33. United Nations. Goal 12. Ensure Sustainable Consumption and Production Patterns (Updated on 3 March 2016); United Nations: New York, NY, USA, 2016.

34. European Commission. Report from the Commission to the European Parliament, the Council, the European Economic and Social Committee and the Committee of the Regions. On the Implementation of the Circular Economy Action Plan; European Commission: Brussels, Belgium, 2019.

35. European Union. Communication from the Commission to the European Parliament, the Council, the European Economic and Social Committee and the Committee of the Regions. Closing the Loop-An EU Action Plan for the Circular Economy; European Union: Brussels, Belgium, 2015.

36. European Comission. Innovating for Sustainable Growth: A Bioeconomy for Europe; European Comission; Office of the European Union: Brussels, Belgium, 2012.

37. European Commission. Horizon 2020 in Brief. The EU Framework Programme for Research E Innovation; Union, E., Ed.; Office of the European Union: Brussels, Belgium, 2014.

38. European Commission. Communication from the Commission to the European Parliament, the Council, the European Economic and Social Committee and the Committee of the Regions. Innovating for Sustainable Growth: A Bioeconomy for Europe; European Commission: Brussels, Belgium, 2012.

39. Bracco, S.; Calicioglu, O.; Gomez San Juan, M.; Flammini, A. Assessing the Contribution of Bioeconomy to the Total Economy: A Review of National Frameworks. Sustainability 2018, 10, 1698. [CrossRef]

40. Mohanty, A.K.; Misra, M.; Drzal, L.T. Sustainable Bio-Composites from renewable resources: Opportunities and challenges in the green materials world. J. Polym. Environ. 2002, 10, 19-26. [CrossRef]

41. European Commission. Review of the 2012 European Bioeconomy Strategy; Office of the European Union: Brussels, Belgium, 2017.

42. German Bioeconomy Council. World Bioeconomy Exhibition. El-Chichakli, B., Kambach, K., Eds.; German Bioeconomy Council: 2018. Available online: https://biooekonomierat.de/fileadmin/Publikationen/Sonstige/ Ausstellungskatalog_final.pdf (accessed on 6 February 2020).

43. Tuck, C.O.; Perez, E.; Horvath, I.T.; Sheldon, R.A.; Poliakoff, M. Valorization of Biomass: Deriving More Value from Waste. Science 2012, 337, 695-699. [CrossRef] [PubMed]

44. McCormick, K.; Kautto, N. The Bioeconomy in Europe: An Overview. Sustainability 2013, 5, 2589. [CrossRef]

45. Bioeconomy Stakeholders Panel. European Bioeconomy Stakeholders. Manifesto; Bioeconomy Stakeholders Panel: Brussels, Belgium, 2017.

46. Ciegis, R.; Ramanauskiene, J.; Martinkus, B. The concept of sustainable development and its use for sustainability scenarios. Eng. Econ. 2009, 2, 28-37.

47. Heimann, T. Bioeconomy and SDGs: Does the Bioeconomy Support the Achievement of the SDGs? Earth's Futur. 2019, 7, 43-57. [CrossRef]

48. International Advisory Council (IAC) GBS2018. Global Bioeconomy Summit Communiqué 2018. Innovation in the Global Bioeconomy for Sustainable and Inclusive Transformation and Wellbeing; International Advisory Council (IAC) GBS2018: Berlin, Germany, 2018.

49. Intharathirat, R.; Abdul Salam, P. Valorization of MSW-to-Energy in Thailand: Status, Challenges and Prospects. Waste Biomass Valorization 2016, 7, 31-57. [CrossRef]

50. Kothari, R.; Tyagi, V.V.; Pathak, A. Waste-to-energy: A way from renewable energy sources to sustainable development. Renew. Sustain. Energy Rev. 2010, 14, 3164-3170. [CrossRef]

51. Junta de Andalucía. Estrategia Andaluza Bioeconomía Circular; Junta de Andalucía: Sevilla, España, 2018. 
52. Baudoin, W.; Nersisyan, A.; Shamilov, A.; Hodder, A.; Gutierrez, D.; Pascale, S.D.e.; Nicola, S.; Chairperson, V.; Gruda, N.; Urban, L.; et al. Good Agricultural Practices for Greenhouse Vegetable Production in the South East European Countries. Principles for Sustainable Intensification of Smallholder Farms; Food and Agriculture Organization of the United Nations: Rome, Italy, 2017.

53. Tüzel, Y.; Leonardi, C. Protected cultivation in Mediterranean region: Trends and needs. J. Ege Univ. Fac. Agric. 2009, 46, 215-223.

54. Baudoin, W.; Nono-Womdim, R.; Lutaladio, N.; Hodder, A.; Castilla, N.; Leonardi, C.; Pascale, S.D.e.; Qaryouti, M. Good Agricultural Practices for Greenhouse Vegetable Crops. Principles for Meditterranean Climate Areas; Food and Agriculture Organization of the United Nations: Rome, Italy, 2013.

55. European Comission. EIP-AGRI Focus Group Circular Horticulture. Final Report. February 2019; eip-agri Agriculture \& Innovation: Brussels, Belgium, 2019.

56. Torrellas, M.; Antón, A.; López, J.C.; Baeza, E.J.; Parra, J.P.; Muñoz, P.; Montero, J.I. LCA of a tomato crop in a multi-tunnel greenhouse in Almeria. Int. J. Life Cycle Assess. 2012, 17, 863-875. [CrossRef]

57. European Commission. EIP-AGRI Workshop Opportunities for Farm Diversification in the Circular Bioeconomy. Final Report. May 2019; eip-agri Agriculture \& Innovation: Brussels, Belgium, 2019.

58. Torrellas, M.; Antón, A.; Ruijs, M.; García Victoria, N.; Stanghellini, C.; Montero, J.I. Environmental and economic assessment of protected crops in four European scenarios. J. Clean. Prod. 2012, 28, 45-55. [CrossRef]

59. Consejería de Agricultura, P.y.D.S. Memoria Resumen 2018. Available online: https://www.juntadeandalucia. es/organismos/agriculturaganaderiapescaydesarrollosostenible/consejeria/sobre-consejeria/estadisticas/paginas/ agrarias-anuario.html (accessed on 6 February 2020).

60. United Nations System Staff College (UNSSC). La Agenda 2030 Para el Desarrollo Sostenible; UNSSC Knowledge Centre for Sustainable Developmen: Bonn, Germany, 2015.

61. Valera, D.L.; Belmonte, L.J.; Molina-Aiz, F.D.; López, A.; Camacho, F. The greenhouses of Almería, Spain: Technological analysis and profitability. Acta Hortic. 2017, 219-226. [CrossRef]

62. Egea, F.J.; Torrente, R.G.; Aguilar, A. An efficient agro-industrial complex in Almería (Spain): Towards an integrated and sustainable bioeconomy model. N. Biotechnol. 2018, 40, 103-112. [CrossRef] [PubMed]

63. Instituto de Estudios de Cajamar. La Economía de la Provincia de Almería; Caja Rural Intermediterránea.Cajamar, Ed.; Instituto de Estudios de Cajamar: Almería, España, 2005; ISBN 84-95531-27-5.

64. Junta de Andalucía-Consejería de Agricultura, P.y.D.R. Cartografía de Invernaderos en Almería, Granada y Málaga; Año 2018. Consejería de Agricultura, Pesca y Desarrollo Rural, 2018. Available online: https: //www.juntadeandalucia.es/export/drupaljda/Cartografia\%20_inv_AL_GR_MA_180725.pdf (accessed on 6 February 2020).

65. Junta de Andalucía-Consejería de Agricultura, P.y.D.R.-O.de P.y M. Evaluación de la Campaña 2017 /18. Hortícolas Protegidos de Almería; Consejería de Agricultura, Pesca y Desarrollo Rural—Observatorio de Precios y Mercados: Sevilla, España, 2018.

66. Honoré, M.N.; Belmonte-Ureña, L.J.; Navarro-Velasco, A.; Camacho-Ferre, F. Profit Analysis of Papaya Crops under Greenhouses as an Alternative to Traditional Intensive Horticulture in Southeast Spain. Int. J. Environ. Res. Public Health 2019, 16, 2908.

67. Junta de Andalucía-Consejería de Agricultura, P.y.D.R.-C.de M.A.y O.del T. Líneas de Actuación en Materia de Gestión de Restos Vegetales en la Horticultura de Andalucía; Consejería de Agricultura, Pesca y Desarrollo Rural—Consejería de Medio Ambiente y Ordenación del Territorio: Sevilla, España, 2016.

68. Hernández, J.C.L.; Martínez, C.P.; Fernández, G.A. Ficha de Transferencia Nro. 017. Residuos Vegetales Procedentes de los Invernaderos de Almería; Cajamar Caja Rural: Almería, España, 2016.

69. Aznar-Sánchez, J.; Belmonte-Ureña, L.; Velasco-Muñoz, J.; Valera, D. Aquifer Sustainability and the Use of Desalinated Seawater for Greenhouse Irrigation in the Campo de Nijar, Southeast Spain. Int. J. Environ. Res. Public Health 2019, 16, 898. [CrossRef] [PubMed]

70. Ministerio de Agricultura, A.y M.A. Produccion y Consumo Sostenibles y Residuos Agrarios; Ministerio de Agricultura, Alimentación y Medio Ambiente: Madrid, España, 2012.

71. Torres Nieto, J.M. Documentos Técnicos No. 10. Cajamar Caja Rural. Uso Agronómico de Restos de Cosecha en Los Invernaderos Enarenados de la Cuenta Mediterránea; Cajamar Caja Rural: Málaga, Spain, 2016.

72. Ministerio de Agricultura y Pesca, A.y.M.A.; Ministerio de Economía, I.y.C. Pacto Por Una Economía Circular: El Compromiso de los Agentes Económicos y Sociales 2018-2020; Ministerio para la Transición Ecológica: Madrid, España, 2017. 
73. European Union. Directive (EU) 2018/2001 of the European Parliament and of the Council on the Promotion of the Use of Energy from Renewable Sources. European Parliament and of the Council of the European Union, 2018. Available online: https://eur-lex.europa.eu/eli/dir/2018/2001/oj (accessed on 7 February 2020).

74. European Union. Directiva 2008/98/CE del Parlamento Europeo y del Consejo de 19 de Noviembre de 2008, Sobre los Residuos y Por la Que se Derogan Determinadas Directivas. Parlamento europeo y el Consejo de la Unión Europea, 2008. Available online: https://eur-lex.europa.eu/legal-content/ES/TXT/?uri=celex\%3A32008L0098 (accessed on 7 February 2020).

75. European Union. Directiva (UE) 2018/851 del Parlamento Europeo y del Consejo de 30 de Mayo de 2018, por la Que se Modifica la Directiva 2008/98/CE Sobre Los Residuos. Parlamento europeo y el Consejo de la Unión Europea, 2018. Available online: https://eur-lex.europa.eu/legal-content/ES/TXT/PDF/?uri=CELEX:32018L0851\&from=EN (accessed on 7 February 2020).

76. Jefatura del estado español-Juan Carlos I-Rey de España. Ley 22/2011, de 28 de Julio, de Residuos y Suelos Contaminados. «BOE» núm. 181, de 29 de julio de 2011 Referencia: BOE-A-2011-13046; Presidente del Gobierno-José Luis Rodríguez Zapatero: Madrid, España, 2016.

77. Jefatura del estado español-Juan Carlos I-Rey de España. Ley 5/2013, de 11 de Junio, Por la Que se Modifican la Ley 16/2002, de 1 de Julio, de Prevención y Control Integrados de la Contaminación, y la Ley 22/2011, de 28 de Julio, de Residuos y Suelos Contaminados; Presidente del Gobierno- Mariano Rajoy Brey: Madrid, España, 2013.

78. European Commission. Commission Decision of 3 May 2000 Replacing Decision 94/3/EC Establishing a List of Wastes Pursuant to Article 1(a) of Council Directive 75/442/EEC on Waste and Council Decision 94/904/EC Establishing a List of Hazardous Waste Pursuant to Article 1(4) of; Commission of the European Communities-Margot WALLSTRÖM: Brussels, Belgium, 2000.

79. European Union. Reglamento (CE) No. 834/2007 del Consejo de 28 de Junio de 2007, Sobre Producción y Etiquetado de Los Productos Ecológicos y por el Que se Deroga el Reglamento (CEE) No. 2092/91; Presidente del Consejo de la Unión Europea-S. Gabriel: Luxembourg, 2007; Available online: https://www.boe.es/doue/2007/189/L0000100023.pdf (accessed on 7 February 2020).

80. European Environment Agency. Circular by Design: Products in the Circular Economy; Office of the European Union: Copenhagen, Denmark, 2017.

81. European Union. The Common Agricultural Policy (CAP) and the Treaty. European Parliament-Albert Massot, 2019. Available online: https://www.europarl.europa.eu/factsheets/en/sheet/103/the-common-agriculturalpolicy-cap-and-the-treaty (accessed on 8 February 2020).

82. European Union. The Post-2020 Common Agricultural Policy: Environmental Benifits and Simplification. European Commission, 2019. Available online: https:/ec.europa.eu/info/sites/info/files/food-farming-fisheries/key_ policies/documents/cap-post-2020-environ-benefits-simplification_en.pdf (accessed on 8 February 2020).

83. Comisión Europea. Reglamento (CE) No. 1698/2005 del Consejo de 20 de Septiembre de 2005, Relativo a la Ayuda al Desarrollo Rural a Través del Fondo Europeo Agrícola de Desarrollo Rural (FEADER). Consejo de la Unión Europea, 2005. Available online: https://eur-lex.europa.eu/LexUriServ/LexUriServ.do?uri=CONSLEG:2005R1698: 20070101:ES:PDF (accessed on 8 February 2020).

84. European Union. Regulation (EU) No 1303/2013 of the European Parliament and of the Council of 17 December 2013, Laying down Common Provisions on the European Regional Development Fund, the European Social Fund, the Cohesion Fund, the European Agricultural Fund for Rural. European Parliament and of the Council of the European Union, 2013. Available online: https://eur-lex.europa.eu/legal-content/EN/TXT/?uri=CELEX:32013R1303 (accessed on 8 February 2020).

85. European Commission. European Structural and Investment Funds 2014-2020: Official Texts and Commentaries; Office of the European Union: Luxembourg, 2015.

86. European Comission. Bioeconomy: The European Way to Use our Natural Resources. Action Plan 2018; Office of the European Union: Brussels, Belgium, 2018.

87. Ministerio de Agricultura y Pesca, A.y.M.A. España_Programa Nacional de Desarrollo Rural 2014-2020. Versión 5.0 (Consolidado con el Marco Nacional2014es06rdnf001-v3.0—Adoptado por la CE); Ministerio de Agricultura y Pesca, Alimentación y Medio Ambiente: Madrid, España, 2018.

88. Ministerio de Agricultura, P.y.A. Resolución de 18 de Junio de 2018, del Fondo Español de Garantía Agraria, O.A. (FEGA) por la Que se Convocan Ayudas Para la Concesión de Subvenciones a la Ejecución de Proyectos de Innovación de Interés General por Grupos Operativos de la Asociación Euro; Miguel Ángel Riesgo Pablo-Presidente del Fondo Español de Garantía Agraria O.A: Madrid, España, 2018. 
89. Ministerio de Agricultura, A.y.M.A. Programa Estatal de Prevención de Residuos 27.11.2013; Secretaría de Estado de Medio Ambiente—Secretaría de Estado de Medio Ambiente—Dirección General de Calidad y Evaluación Ambiental y Medio Natural: Madrid, España, 2013.

90. Ministerio de Economía y Competitividad. Estrategia Española de Bioeconomía. Horizonte 2030; Ministerio de Economía y Competitividad-Secretaria de Estado de Investigación, Desarrollo e Innovación: Madrid, España, 2015.

91. Ministerio de Agricultura, A.y.M.A. Plan Estatal Marco de Gestión de Residuos (PEMAR) 2016-2022; Secretaría de Estado de Medio Ambiente-Dirección General de Calidad y Evaluación Ambiental y Medio Natural: Madrid, España, 2016.

92. Ministerio de Agricultura y Pesca, A.y.M.A. Estrategia Para la Producción Ecológica 2018-2020; Ministerio de Agricultura y Pesca, Alimentación y Medio Ambiente: Madrid, España, 2018.

93. Camacho-Ferre, F. Diferentes alternativas para la gestión del residuo biomasa procedente de cultivos de invernadero. In Innovaciones Tecnológicas en Cultivos de Invernadero; Rodríguez, E.J.F., Ed.; Universidad de Almería-Junta de Andalucía: Almería, España, 2003.

94. Camacho Ferre, F. Estudio Técnico de Plan de Higiene Rural. Término Municipal de Níjar; Níjar Natura: Almería, España, 2000.

95. Reche Mármol, J. Cultivo del Pimiento Dulce en Invernadero; Junta de Andalucía. Consejería de Agricultura y Pesca, Ed.; Signatura; Secretaría General Técnica. Servicio de Publicaciones y Divulgación: Sevilla, España, 2010.

96. Callejón, A.J.; Carreño, A.; Sánchez-Hermosilla, J.; Pérez, J. Evaluación de impacto ambiental de centro de transformación y gestión de residuos sólidos agrícolas en la provincia de Almería (España). Inf. la Construcción 2010, 62, 79-93. [CrossRef]

97. Callejón-Ferre, A.J.; Velázquez-Martí, B.; López-Martínez, J.A.; Manzano-Agugliaro, F. Greenhouse crop residues: Energy potential and models for the prediction of their higher heating value. Renew. Sustain. Energy Rev. 2011, 15, 948-955.

98. Manzano Agugliaro, F. Gasificacion de residuos de invernadero para la obtención de energía eléctrica en el sur de España: Ubicación mediante SIG. Interciencia 2007, 32, 1-7.

99. Galdeano-gómez, E.; Aznar-sánchez, J.A.; Pérez-mesa, J.C. Contribuciones Económicas, Sociales y Medioambientales de la Agricultura Intensiva de Almería. Un Análisis de Sinergias Entre las Dimensiones de Sostenibilidad; Cajamar, C.R., Ed.; Cajamar Caja Rural: Almería, España, 2016.

100. Junta de Andalucía-Consejería de Agricultura, P.y.D.R. Caracterización de Las Explotaciones de Invernadero de Andalucía: Campo de Dalías (Almería); Consejería de Agricultura, Pesca y Desarrollo Rural—Observatorio de Precios y Mercados: Sevilla, Spain, 2015.

101. Junta de Andalucía-Consejería de Agricultura, P.y.D.R. Caracterización de los Invernaderos de Andalucía; Consejería de Agricultura, Pesca y Desarrollo Rural-Observatorio de Precios y Mercados: Sevilla, Spain, 2015.

102. Junta de Andalucía-Consejería de Agricultura, P.y.D.R. Caracterización de las Explotaciones de Invernadero de Andalucía: Campo de Níjar y Bajo Andarax (Almería); Consejería de Agricultura, Pesca y Desarrollo Rural-Observatorio de Precios y Mercados: Sevilla, Spain, 2015.

103. Junta de Andalucía-Consejería de Agricultura, P.y.D.R.-S.G.de A.y.A. El Sector Agrario y Pesquero en Andalucía; Consejería de Agricultura, Pesca y Desarrollo Rural: Sevilla, Spain, 2017.

104. Ministerio de Agricultura y Pesca, A.y.M.A.-S.G.de C.D.y.A.E. Agricultura Ecológica-Estadísticas 2017; Ministerio de Agricultura y Pesca, Alimentación y Medio Ambiente-Subdirección General de Calidad Diferenciada y Agricultura Ecológica: Sevilla, Spain, 2018.

105. García García, M.C.; Céspedes López, A.J.; Pérez Parra, J.J.; Lorenzo Mínguez, P. El Sistema de Producción Hortícola Protegido de la Provincia de Almería; Instituto de investigación y Formación Agraria y Pesquera (IFAPA): Almería, España, 2016.

106. Junta de Andalucía-Consejería de Agricultura, P.y.D.R. Caracterización de Las Explotaciones de Invernadero de Andalucía: Otras Zonas; Consejería de Agricultura, Pesca y Desarrollo Rural-Observatorio de Precios y Mercados: Sevilla, Spain, 2015.

107. Junta de Andalucía-Consejería de Economía y Conocimiento. Decreto 1/2016, de 12 de Enero, Por el Que se Establece un Conjunto de Medidas Para la Aplicación de la Declaración Responsable Para Determinadas Actividades Económicas Reguladas en la Ley 3/2014, de 1 de Octubre, de Medidas Normativas Para Reducir Las tr. Consejería de Economía y Conocimiento, 2016. Available online: https://www.juntadeandalucia.es/boja/2016/9/1 (accessed on 8 February 2020). 
108. Lefèvre, C.; Fatma, R.; Viridiana, A.; Liesl, W. Soil Organic Carbon the Hidden Potential; Liesl, W., Viridiana, A., Rainer, B., Ronald, V., Eds.; Food and Agriculture Organization of the United Nations: Rome, Italy, 2017.

109. Callejón-Ferre, A.J.; Carreño-Sánchez, J.; Suárez-Medina, F.J.; Pérez-Alonso, J.; Velázquez-Martí, B. Prediction models for higher heating value based on the structural analysis of the biomass of plant remains from the greenhouses of Almería (Spain). Fuel 2014, 116, 377-387. [CrossRef]

110. Aguilera-Sáez, L.M.; Arrabal-Campos, F.M.; Callejón-Ferre, Á.J.; Suárez Medina, M.D.; Fernández, I. Use of multivariate NMR analysis in the content prediction of hemicellulose, cellulose and lignin in greenhouse crop residues. Phytochemistry 2019, 158, 110-119. [CrossRef]

111. Morales, L.; Garzón, E.; Martínez-Blanes, J.M.; Sánchez-Soto, P.J. Thermal study of residues from greenhouse crops plant biomass. J. Therm. Anal. Calorim. 2017, 129, 1111-1120. [CrossRef]

112. Garzón, E.; Morales, L.; Martínez-Blanes, J.M.; Sánchez-Soto, P.J. Characterization of ashes from greenhouse crops plant biomass residues using X-ray fluorescence analysis and X-ray diffraction. X Ray Spectrom. 2017, 46, 569-578. [CrossRef]

113. Sánchez-Molina, J.A.; Reinoso, J.V.; Acién, F.G.; Rodríguez, F.; López, J.C. Development of a biomass-based system for nocturnal temperature and diurnal $\mathrm{CO} 2$ concentration control in greenhouses. Biomass Bioenergy 2014, 67, 60-71. [CrossRef]

114. Pinna-Hernández, M.G.; Martínez-Soler, I.; Díaz Villanueva, M.J.; Acien Fernández, F.G.; López, J.L.C. Selection of biomass supply for a gasification process in a solar thermal hybrid plant for the production of electricity. Ind. Crops Prod. 2019, 137, 339-346. [CrossRef]

115. Reinoso, J.V.; Acién, F.G.; Fernández, M.D.; López, J.C.; Sánchez, J.A.; Rodríguez, F. Caracterización de los Residuos Vegetales de Invernadero Para su Aprovechamiento en Sistemas de Calefacción y Enriquecimiento. Actas del II Simposio Nacional de Ingeniería Hortícola realizado del 10 al 12 de febrero de 2016, en Almería, España.

116. Acién Fernández, F.G.; Fernández Sevilla, J.M.; López Hernández, J.C.; Fernández Fernández, M.D.; Rodríguez Díaz, F.D.A.; Sánchez Molina, J.A. Sistema Combinado de Calefacción y Enriquecimiento Carbónico a Partir de Biomasa. Available online: http://repositorio.ual.es/handle/10835/4390 (accessed on 8 February 2020).

117. Callejón-Ferre, A.J.; López-Martínez, J.A.; López-Martínez, J.A. Briquettes of plant remains from the greenhouses of Almería (Spain). Span. J. Agric. Res. 2009, 7, 525. [CrossRef]

118. Márquez, M.A.; Diánez, F.; Camacho, F. The use of vegetable subproducts from greenhouses (VSG) for animal feed in the Poniente region of Almería. Renew. Agric. Food Syst. 2011, 26, 4-12. [CrossRef]

119. Parra, S.; Aguilar, F.J.; Calatrava, J. Decision modelling for environmental protection: The contingent valuation method applied to greenhouse waste management. Biosyst. Eng. 2008, 99, 469-477. [CrossRef]

120. Gómez-Tenorio, M.A.; Lupión-Rodríguez, B.; Boix-Ruiz, A.; Ruiz-Olmos, C.; Marín-Guirao, J.I.; Tello-Marquina, J.C.; Camacho-Ferre, F.; de Cara-García, M. Meloidogyne-infested tomato crop residues are a suitable material for biodisinfestation to manage Meloidogyne sp. in greenhouses in Almería (south-east Spain). Acta Hortic. 2018, 217-222.

121. Veeken, A.; Adani, F.; Fangueiro, D.; Jensen, S. EIP-AGRI Focus Group -Nutrient Recycling. The Value of Recycling Organic Matter to Soils. Classification as Organic Fertiliser or Organic Soil Improver. eip-agri Agriculture \& Innovation-European Commission, 2017. Available online: http:/circulairterreinbeheer.nl/wp-content/uploads/ 2017/10/Value-of-organic-matter-Classification-as-fertiliser-or-soil-improver_final-23-Jan-2017.pdf (accessed on 8 February 2020).

122. Junta de Andalucía. Orden de 16 de febrero de 2018, por la que se efectúa la convocatoria para el año 2018 de Subvenciones a la Medida 10: Agroambiente y Clima, a la Medida 11: Agricultura Ecológica y a la Medida 13: Pagos a Zonas con Limitaciones Naturales u Otras Limitacio; Consejería de Agricultura, Pesca y Desarrollo Rural-Observatorio de Precios y Mercados: Sevilla, Spain, 2018.

123. Del Moral, F.; González, V.; Simón, M.; García, I.; Sánchez, J.A.; De Haro, S. Soil properties after 10 years of organic versus conventional management in two greenhouses in Almeria (SE Spain). Arch. Agron. Soil Sci. 2012, 58, S226-S231. [CrossRef] 
124. Becker, S.J.; Ebrahimzadeh, A.; Plaza Herrada, B.M.; Lao, M.T. Characterization of Compost Based on Crop Residues: Changes in Some Chemical and Physical Properties of the Soil after Applying the Compost as Organic Amendment. Commun. Soil Sci. Plant Anal. 2010, 41, 696-708. [CrossRef]

125. García-Raya, P.; Ruiz-Olmos, C.; Marín-Guirao, J.; Asensio-Grima, C.; Tello-Marquina, J.; de Cara-García, M. Greenhouse Soil Biosolarization with Tomato Plant Debris as a Unique Fertilizer for Tomato Crops. Int. J. Environ. Res. Public Health 2019, 16, 279. [CrossRef]

(C) 2020 by the authors. Licensee MDPI, Basel, Switzerland. This article is an open access article distributed under the terms and conditions of the Creative Commons Attribution (CC BY) license (http://creativecommons.org/licenses/by/4.0/). 